\title{
Application of Ethnobotanical Indices to Assess the Diversity of Medico- magic Knowledge on Four Herbaceous Species in Benin.
}

\author{
Hubert Olivier Dossou-Yovo ( $\square$ dohuoly@yahoo.fr) \\ Laboratory of Applied Ecology https://orcid.org/0000-0001-9913-6626 \\ Valentin Kindomihou \\ Laboratory of Applied Ecology, Faculty of Agronomic Sciences, University of Abomey-Calavi. \\ Brice Sinsin \\ Laboratory of Applied Ecology, Faculty of Agronomic Sciences, University of Abomey-Calavi.
}

\section{Research}

Keywords: Ethnobotanical Indices, Herbaceous, Medicinal, Magic Exploitation

Posted Date: October 27th, 2020

DOl: https://doi.org/10.21203/rs.3.rs-96891/v1

License: @ (i) This work is licensed under a Creative Commons Attribution 4.0 International License. Read Full License 


\section{Abstract \\ Background}

Ethnobotanical knowledge on four herbaceous species, Phyllanthus amarus, Spilanthes uliginosa, Momordica charantia and Acalypha ciliata in Benin was investigated.

\section{Methods}

Thirty-six herbal medicine traders in six different markets were interviewed using a semi-structured questionnaire. The Relative Frequency Citation, Fidelity Level, Use Value and Rahman Similarity Index were calculated to assess the diversity of medico-magic knowledge.

\section{Results}

All informants traded $P$. amarus, $M$. charantia and $A$. ciliata and the majority traded $S$. uliginosa. Purchase in traders' own markets was the predominant source of $P$. amarus, $M$. charantia and $A$. ciliata while $S$. uliginosa was mostly purchased in other more distant markets. A noticeable proportion of traders also collect $P$. amarus and $M$. charantia from wild populations. Phyllanthus amarus was the species most demanded by customers followed by M. charantia. Traders confirmed the scarcity of all species in recent years and climate change as well as destruction of natural habitats for logging were the most cited causes. The entire plant of $P$. amarus was used mainly to treat malaria, diabetes and constipation and decoction with oral administration the most frequent preparation for malaria treatment. To treat diabetes, informants mixed $P$. amarus with $M$. charantia used as a decoction with oral administration. Momordica charantia was also used to treat measles and chicken pox. Spilanthes uliginosa and $A$. ciliata were mostly used for their spiritual use for luck, predominantly by chewing fresh leaves or flowers, and by bathing with the ground plant mixed with soap, respectively. Overall, $M$. charantia had the greatest use value followed by $P$. amarus. The majority of traders do not plant the species.

\section{Conclusions}

The harvesting and trade of the species threaten their natural populations and urgent tools, including in-situ and ex-situ conservation, are needed to ensure their long-term sustainable exploitation.

\section{Introduction}

The green medicine is obviously of major importance to mankind [1-3]. Gathering of high value products including medicinal plants from the wild continues in developing countries $[3,4]$. Moreover, medicinal plants harvested from the wild serve as raw materials for commercial pharmaceutical factories $[3,5]$. Thus, medicinal plants are important in both developed and developing countries and there is an increasing need to gather knowledge related to their exploitation and to define conservation strategies for long-term exploitation. Amongst medicinal plants, herbs have a great importance [6, 7] as they are accessible to many people.

Ethnobotanical indices have been applied to evaluate ethnobotanical knowledge on plant species in other parts of the world [8-10] but not in Benin. Indeed, quantitative ethnobotany is concerned with measuring the importance of plants and vegetation for human well-being, as well as it relies on cultural significance indices as quantitative tools for qualitative data [11-13]. Because this approach is likely to generate data that lend themselves to hypothesis testing, statistical validation and comparative analysis [10], applying specific ethnobotanical indices may either serves in analysing the range of information related to plants used for medico-magic purposes. The present research focused on four herbaceous species known as medicinal plants in Benin, Phyllanthus amarus Schumach. \& Thonn., Spilanthes uliginosa Sw., Momordica charantia L. and Acalypha ciliata Farssk.. These species have been reported as used in green medicine in many parts of the world [14-17]. There is a lack of ethnobotanical information on them in Benin although Boko-Haya et al. [18] reported the ethnic differences in use of $P$. amarus in Northern Benin. Many years ago, this species was also tested for its antiplasmodial activity in Benin [19]. The aim of the present research was to document the medico-magic knowledge held by herbal medicine traders on these herbaceous species in Southern Benin through the application of four ethnobotanical indices i.e. Relative Frequency Citation [20, 21, Fidelity Level [22-24], Use Value [20, 21, 25], and the Rahman Similarity Index [26].

\section{Material And Methods}

\section{1-Study species}

Phyllanthus amarus Schumach. \& Thonn., (Hinlinwé in Fon), belongs to Euphorbiaceae, is an annual herb, $60-75 \mathrm{~cm}$ tall and quite glabrous. Its roots are stout and woody; the stems are branched at the base and angular with numerous leaves. The plant naturally grows in tropical and subtropical climates on well drained sandy-loam soils [27]. It protects the liver and limits the effects of viral hepatitis A, B, and C, reduces type 2 diabetes, helps fighting cancer and detoxifie the body [28]. 
Spilanthes uliginosa Sw. (Awélékpékpé in Fon), as an Asteraceae, is an annual herb with simple leaves and pungent flowers [29], liking humid places and superficially drained Sudanian swamps, and sometimes ruderal. The species is used for dental problems and for its antiseptic, homeostatic, analgesic, insecticidal and anti-inflammatory activity [30].

Momordica charantia L. (Yinsinkin in Fon), from Cucurbitaceae, commonly called bitter-melon or ampalaya, grows 12 to $20 \mathrm{~cm}$ long. Its fruits ripen from green to yellow and ripe fruits are ornamentally attractive but malodorous [31]. It is a pantropical vegetable originated in tropical Africa [32]. Fruit also is carminative, tonic, stomachic, aphrodisiac, anthelmintic, astringent to bowels and useful in treatment of syphilis, rheumatism, spleen troubles, and effectiveness in treating diabetes [33].

Acalypha ciliata Farssk. (Viviman téton in Fon), is an Euphorbiaceae occurring widely in Africa. It is uncommon crop weed in heavily watered areas [34, 35], a monoecious annual herb tilled up to $1 \mathrm{~m}$ with simple leaves at $2 \mathrm{~mm}$ long stipules linear at blade ovate. Fruits are 3-lobed capsule, smooth, almost glabrous [36]. Foliar powder or infusion is used for maggot-infested wounds [37].

\section{Ethnobotanical data collection}

Two markets in each of three districts of Benin were surveyed, Pahou and Zobê in Ouidah District, Cococodji and Godomey in Abomey-Calavi District, Vêdoko and Dantokpa in Littoral District. Six herbal medicine traders were randomly selected in each market and ethnobotanical data were gathered from them on each of the four study species. A total of 36 traders were thus surveyed. A semi-structured questionnaire was used in collecting data on the trade, sources and importance of each species. Traders were asked to rank the four species according to consumer demand and the availability versus scarcity of each species in recent years. The various causes of scarcity were also recorded. In addition, herbal medicine traders were asked to list all diseases, disorders and magic issues treated using each species as well as all types of preparation used for these purposes. In order to assess traders' contribution to the research species conservation, the plantation or in-situ conservation of each species by traders and their motives were investigated. Each time an informant confirmed the trade of a species, they were asked to show a sample for positive identification. All interviews were conducted in the local language, Fon, well spoken and understood by all informants.

\section{Ethnobotanical indices calculation for data analysis}

(a) The Relative Frequency Citation (RFC) $[20,21]$, was calculated using the following formula:

$$
R F C=\frac{n_{i}}{N} X 100,(1)
$$

where $n_{i}$ is the number of informants who mentioned the concerned species, thing or aspect and $N$ is the total number of surveyed traders.

(b) The Fidelity Level (FL) [22 - 24] was determined for the diseases as follows;

$$
F L(\%)=\frac{I_{P}}{I_{U}} \times 100,(2)
$$

where $I_{p}$ is the number of informants who mentioned the use of a species for a specific disease, disorder or magic issue and $I_{u}$ is the total number of informants who mentioned the species for any use. The FL was also calculated in a similar way for the types of preparation recorded for each disease, disorder or magic issue. The FL served to assess the informants' preference for a species to treat a specific disease, disorder or magic issue. It also served to assess the preference for a specific type of preparation. FL ranges from zero to a hundred per cents and a value close to $100 \%$ means a high preference.

(c) The Use Value (UV) of each species was determined [20, 21, 25].

$$
\mathrm{UV}=\frac{n_{d}}{\mathrm{I}_{\mathrm{U}}},(3)
$$

where $n_{d}$ is the total number of use reports (diseases, disorders or magic utilization) mentioned for a species and $I_{u}$ is the total number of informants who mentioned the species for any use. The use value served to compare the relative importance of the study species in terms of uses.

(d) The ethnobiological Rahman Similarity Index (RSI) [26], to assess the similarity between species in terms of uses, was calculated as follow:

This formula is similar to the Jaccard Similarity Index. Rahman et al. [26] considered an ailment recorded in two communities and treated with a number of medicinal plant species, species commonly used in both communities. In the present research, this approach was adapted to similarity of uses of pairs of species with, respectively, $n_{a}$ and $n_{b}$ as number of use reports in species a and $b$ and, the number of common uses recorded for the two species as $n_{c}$. RSI can range from 0 to $100 \%$ and an RSI lower than $50 \%$ means low similarity in terms of uses between the two species while an RSI higher than $50 \%$ indicates a high similarity of uses between the two species. 


\section{Results}

\section{Sources of the species traded.}

All informants traded $P$. amarus, $M$. charantia and $A$. ciliata while $95 \%$ of informants traded trade $S$. uliginosa. Samples of each species were shown by each trader as proof. With regards to the sources of each species traded (Table 1), six different sources were recorded and the majority of informants purchase $P$. amarus, $S$. uliginosa and $M$. charantia in both their own markets and other distant markets. In addition to these sources, a relatively large proportion of traders collect plants from wild populations of $P$. amarus and $M$. charantia. Traders mostly got $A$. ciliata by purchasing it in their own markets and collecting the species from the wild. The single most important source of each species reported by herbal medicine traders was their own market for $P$. amarus (44\% of traders), M. charantia (50\% of traders) and A. ciliata (39\% of traders), while for S. uliginosa it was distant markets (39\% of traders).

Table 1

Sources of the study species according to traders.

\begin{tabular}{|llllll|}
\hline & $\begin{array}{l}\text { Purchase in their } \\
\text { markets }\end{array}$ & $\begin{array}{l}\text { Purchase in } \\
\text { nearby markets }\end{array}$ & $\begin{array}{l}\text { Purchase in } \\
\text { distant markets }\end{array}$ & $\begin{array}{l}\text { Purchase in } \\
\text { gardens }\end{array}$ & $\begin{array}{l}\text { Collection from the wild } \\
\text { populations }\end{array}$ \\
\cline { 2 - 5 } & RFC (\%) & RFC (\%) & RFC (\%) & $\begin{array}{l}\text { Collection from } \\
\text { own gardens }\end{array}$ \\
\hline $\begin{array}{l}\text { Phyllanthus } \\
\text { amarus }\end{array}$ & 83 & 17 & 50 & 6 & RFC (\%) \\
\hline $\begin{array}{l}\text { Spilanthes } \\
\text { uliginosa }\end{array}$ & 72 & 11 & 50 & 17 & 0 \\
\hline $\begin{array}{l}\text { Momordica } \\
\text { charantia }\end{array}$ & 78 & 11 & 44 & 0 & 44 \\
\hline $\begin{array}{l}\text { Acalypha } \\
\text { ciliata }\end{array}$ & 56 & 11 & 33 & 0 & 44 \\
\hline *RFC (\%) $=$ Relative Frequency Citation (\%). Number of traders $=36$. & & 6 \\
\hline
\end{tabular}

\section{Ranking of the species in terms of demand and availability.}

With regards to their demand, P. amarus was ranked as first by $72 \%$ of traders, S. uliginosa by $22 \%, M$. charantia by $6 \%$, and $A$. ciliata by $0 \%$ (Table 2 ). The majority of surveyed traders confirmed the scarcity rather than easy availability of all four species in recent years. The percentage of traders reporting scarcity was $94 \%$ for $M$. charantia, $89 \%$ for $P$. amarus, $83 \%$ for $A$. calypha and $67 \%$ for $S$. uliginosa. Eight different factors causing scarcity were reported by the herbal medicine traders (Table 3). Climate change and destruction for logging were the top two causes for all four species with overexploitation also mentioned as an equal second cause for $S$ uliginosa.

Table 2

Ranking of the study species by demand according to their traders

\begin{tabular}{|lllll|}
\hline & \multicolumn{2}{l|}{ RFC (\%) } & & \\
\cline { 2 - 5 } & 1st rank & 2nd rank & 3rd rank & 4th rank \\
\hline Phyllanthus amarus & 72 & 6 & 16 & 6 \\
\hline Spilanthes uliginosa & 22 & 22 & 36 & 11 \\
\hline Momordica charantia & 6 & 56 & 22 & 17 \\
\hline Acalypha ciliata & 0 & 16 & 28 & 56 \\
\hline${ }^{*}$ RFC (\%) = Relative Frequency Citation (\%). Number of traders = 36 except for S. uliginosa where $\mathrm{n}=34$. \\
\hline
\end{tabular}


Table 3

Causes of scarcity of the study species according to traders.

\begin{tabular}{|c|c|c|c|c|c|c|c|c|}
\hline & \multicolumn{8}{|l|}{$\operatorname{RFC}(\%)^{*}$} \\
\hline & $\begin{array}{l}\text { Destruction } \\
\text { for logging }\end{array}$ & $\begin{array}{l}\text { Climate } \\
\text { change }\end{array}$ & $\begin{array}{l}\text { Population } \\
\text { growth }\end{array}$ & $\begin{array}{l}\text { Over- } \\
\text { exploitation }\end{array}$ & $\begin{array}{l}\text { International } \\
\text { trade }\end{array}$ & $\begin{array}{l}\text { Over exploitation due to } \\
\text { Covid-19 pandemic }\end{array}$ & $\begin{array}{l}\text { Cultivation of } \\
\text { humid areas }\end{array}$ & $\begin{array}{l}\text { Loss of } \\
\text { soil } \\
\text { fertility }\end{array}$ \\
\hline $\begin{array}{l}\text { Phyllanthus } \\
\text { amarus }\end{array}$ & 44 & 67 & 6 & 17 & 6 & 11 & 0 & 6 \\
\hline $\begin{array}{l}\text { Spilanthes } \\
\text { uliginosa }\end{array}$ & 17 & 44 & 0 & 17 & 0 & 0 & 0 & 0 \\
\hline $\begin{array}{l}\text { Momordica } \\
\text { charantia }\end{array}$ & 39 & 78 & 6 & 17 & 0 & 11 & 0 & 0 \\
\hline $\begin{array}{l}\text { Acalypha } \\
\text { ciliata }\end{array}$ & 28 & 67 & 6 & 6 & 0 & 0 & 6 & 6 \\
\hline
\end{tabular}

3. Uses recorded for each species.

Ten uses were recorded for $P$. amarus parts or the entire plant (Table 4). The most frequently (FL in \%) reported use was to treat malaria using the entire plant as medicine, followed by treatment of diabetes, while the same proportion of traders reported the use of this species to treat constipation and stomach aches. Most informants (14 out 16; 88\%) who mentioned use of $P$. amarus to treat diabetes insisted on its combination with $M$. charantia. Three spiritual and one medicinal uses were recorded for $S$. uliginosa (Table 4). All herbal medicine traders reported the spiritual utilization of this species for luck, but it was also used to treat mouth sores. Fifteen uses were recorded for M. charantia (Table 4). All traders mentioned the use of this species to treat measles and chicken pox. All informants who mentioned the use of this species to treat diabetes (39\%) insisted on its mixture with $P$. amarus. Acalypha ciliata was recorded as used to treat eight diseases, disorders and magic issues (Table 4). The most reported use of this species (FL= $86 \%$ ) was its spiritual use for luck. 
Table 4

Fidelity Level (FL\%) of recorded diseases, disorders and magic uses per study species.

\begin{tabular}{|c|c|c|c|c|c|}
\hline \multirow[b]{2}{*}{ Situations types } & \multirow[t]{2}{*}{ List of Social situations recorded } & \multicolumn{4}{|c|}{ Plant species and FL (\%)* } \\
\hline & & Phyllanthus amarus & Spilanthes uliginosa & Momordica charantia & Acalypha ciliata \\
\hline \multirow[t]{4}{*}{ Diseases } & Diabetes & 44 & 0 & 39 & 0 \\
\hline & Infant intelligence stimulation & 0 & 0 & 0 & 6 \\
\hline & Malaria & 67 & 0 & 22 & 9 \\
\hline & Tiredness of old persons & 6 & 0 & 0 & 0 \\
\hline \multirow[t]{4}{*}{ Magic utilization } & Spiritual use for luck & 0 & 100 & 0 & 86 \\
\hline & Spiritual use to in Vodun ${ }^{\dagger}$ & 0 & 12 & 22 & 0 \\
\hline & Spiritual use for self- protection & 0 & 6 & 0 & 0 \\
\hline & Spiritual use for love & 0 & 0 & 0 & 3 \\
\hline \multirow[t]{14}{*}{ Infections } & Chicken pox & 0 & 0 & 100 & 0 \\
\hline & Constipation & 33 & 0 & 14 & 0 \\
\hline & Cough & 0 & 0 & 0 & 17 \\
\hline & Deworming & 6 & 0 & 0 & 0 \\
\hline & Dog bite & 0 & 0 & 6 & 0 \\
\hline & Eye infection & 0 & 0 & 6 & 0 \\
\hline & Fever & 0 & 0 & 14 & 0 \\
\hline & Mouth sore & 0 & 6 & 0 & 0 \\
\hline & Measles & 0 & 0 & 100 & 0 \\
\hline & Laxative use & 0 & 0 & 8 & 0 \\
\hline & Skin infection & 0 & 0 & 6 & 0 \\
\hline & Stomach infection & 28 & 0 & 17 & 0 \\
\hline & Vaginal infection & 0 & 0 & 6 & 0 \\
\hline & Urinary tract infection & 0 & 0 & 6 & 0 \\
\hline \multirow[t]{5}{*}{ Disorders } & Male aphrodisiac & 0 & 0 & 0 & 11 \\
\hline & Female aphrodisiac & 0 & 0 & 0 & 11 \\
\hline & Male impotence & 0 & 0 & 0 & 6 \\
\hline & Stomach ache & 33 & 0 & 0 & 0 \\
\hline & Liver disorder & 6 & 0 & 0 & 0 \\
\hline
\end{tabular}

\section{Relative importance of species and their similarity in terms of uses.}

All species exhabited a Use Value lower than 0.5 (Table 5). However, M. charantia was relatively the most important in terms of uses. The Rahman Similarity Index for uses of pairs of species (Table 5) confirmed an absence of similarity of use between $P$. amarus and both $A$. ciliata and $S$. uliginosa, and also between $M$. charantia and S. uliginosa. However, there was a moderate similarity of use between $P$. amarus and $M$. charantia with both used to treat stomach complaints, malaria, diabetes and constipation. There were very low similarities of use between $M$. charantia and $A$. ciliata, and between $S$. uliginosa and $A$. ciliata with these pairs of species used in common to treat malaria and for good luck, respectively. 
Table 5

Relative importance of the study species (Use Value)

\begin{tabular}{|c|c|c|c|c|c|}
\hline \multirow[t]{2}{*}{ Species } & \multirow[t]{2}{*}{ Total no. of uses } & \multirow[t]{2}{*}{ Use Value (UV) } & \multicolumn{3}{|c|}{$\begin{array}{l}\text { Number of shared uses/ } \\
\text { Rahman Similarity Index (RSI \%) }\end{array}$} \\
\hline & & & Phyllanthus amarus & Spilanthes uliginosa & Momordica charantia \\
\hline Phyllanthus amarus & 10 & 0.27 & - & - & - \\
\hline \multirow[t]{2}{*}{ Spilanthes uliginosa } & 4 & 0.11 & 0 & - & - \\
\hline & & & 0 & & \\
\hline \multirow[t]{2}{*}{ Momordica charantia } & 15 & 0.41 & 4 & 0 & - \\
\hline & & & 19 & 0 & \\
\hline \multirow[t]{2}{*}{ Acalypha ciliata } & 8 & 0.22 & 0 & 1 & 1 \\
\hline & & & 0 & 5 & 5 \\
\hline
\end{tabular}

\section{Preparation and modes of administration}

\section{Phyllanthus amarus}

Based on the Fidelity Level, the three major conditions treated with this species were malaria, diabetes and constipation, the last chosen in this table instead of stomach ache although having equal FL (Table 6). Four types of preparation were mentioned by informants for malaria treatment and three for the other two conditions. For each condition, the majority of traders suggested the use of the entire plant as a decoction and the route of administration was oral. An infusion of the entire plant in a traditional alcoholic drink or in hot water was also mentioned by a minority of the traders to treat all three conditions. A mixture of the dried, powdered plant in an alcoholic drink was reported as a treatment only for malaria. 
Table 6

Fidelity Level (FL \%) of the preparations used for the main purposes for each species.

\begin{tabular}{|c|c|c|c|c|c|c|c|c|}
\hline \multirow[t]{3}{*}{ Preparation } & \multicolumn{8}{|l|}{$\mathrm{FL}(\%)^{*}$} \\
\hline & \multicolumn{3}{|c|}{$\begin{array}{l}\text { Phyllanthus } \\
\text { Amarus }\end{array}$} & \multirow{2}{*}{$\begin{array}{l}\begin{array}{l}\text { Spilanthes } \\
\text { uliginosa }\end{array} \\
\text { Luck } \\
\mathrm{n}=34\end{array}$} & \multicolumn{3}{|c|}{$\begin{array}{l}\text { Momordica } \\
\text { charantia }\end{array}$} & \multirow{2}{*}{$\begin{array}{l}\text { Acalypha } \\
\text { ciliata }\end{array}$} \\
\hline & $\begin{array}{l}\text { Malaria } \\
n=24^{\dagger}\end{array}$ & $\begin{array}{l}\text { Diabetes } \\
n=16\end{array}$ & $\begin{array}{l}\text { Constipation } \\
n=12\end{array}$ & & $\begin{array}{l}\text { Measles } \\
n=36\end{array}$ & $\begin{array}{l}\text { Chicken } \\
\text { pox } \\
n=36\end{array}$ & $\begin{array}{l}\text { Diabetes } \\
n=14\end{array}$ & \\
\hline Decoction of the entire plant for drinking & 88 & 88 & 50 & - & - & - & - & - \\
\hline $\begin{array}{l}\text { Entire plant dried, powdered and mixed in } \\
\text { traditional alcoholic drink 'sodabi' }\end{array}$ & 17 & 0 & 0 & - & - & - & - & - \\
\hline $\begin{array}{l}\text { Entire plant infused in traditional alcoholic } \\
\text { drink }\end{array}$ & 21 & 13 & 37 & - & 17 & 17 & 14 & - \\
\hline Entire plant infused in hot water for drinking & 8 & 25 & 17 & - & 0 & 0 & 29 & - \\
\hline Leaves chewed & - & - & - & 82 & - & - & - & 16 \\
\hline Flowers chewed & - & - & - & 62 & - & - & - & - \\
\hline Leaves and flowers chewed & - & - & - & 6 & - & - & - & - \\
\hline $\begin{array}{l}\text { Entire plant infusion in traditional alcoholic } \\
\text { drink }\end{array}$ & - & - & - & 24 & - & - & - & - \\
\hline $\begin{array}{l}\text { Entire plant pounded and mixed with soap for } \\
\text { bathing }\end{array}$ & - & - & - & 24 & - & - & - & 13 \\
\hline $\begin{array}{l}\text { Infusion of leaves and stems in water used as } \\
\text { a spray }\end{array}$ & - & - & - & 6 & - & - & - & 19 \\
\hline $\begin{array}{l}\text { Infusion of pounded entire plant in water used } \\
\text { as a spray }\end{array}$ & - & - & - & 24 & - & - & - & 6 \\
\hline $\begin{array}{l}\text { Decoction of leaves and stems in water for } \\
\text { drinking }\end{array}$ & - & - & - & - & 25 & 25 & 86 & - \\
\hline Leaves and stems ground in water for bathing & - & - & - & - & 17 & 17 & 0 & - \\
\hline Plant ground in water for drinking & - & - & - & - & 22 & 22 & 0 & - \\
\hline Plant ground in water for drinking and bathing & - & - & - & - & 28 & 28 & 0 & - \\
\hline $\begin{array}{l}\text { Leaves and stems ground in traditional } \\
\text { alcoholic drink 'sodabi' }\end{array}$ & - & - & - & - & 47 & 47 & 0 & - \\
\hline $\begin{array}{l}\text { Leaves and stems ground in natural lemon } \\
\text { juice for drinking }\end{array}$ & - & - & - & - & 11 & 11 & 0 & \\
\hline Entire plant ground in water for bathing & - & - & - & - & & & & 10 \\
\hline $\begin{array}{l}\text { Entire plant ground and mixed with soap for } \\
\text { bathing }\end{array}$ & - & - & - & - & & & & 58 \\
\hline
\end{tabular}

\section{Spilanthes uliginosa}

Only the spiritual use of this species for luck was considered. Seven preparations were mentioned by medicinal plant traders (Table 6). Most commonly reported was the chewing of the leaves followed by the chewing of flowers early in the morning to request for good luck in any kind of business

\section{Momordica charantia}

The three major conditions treated using this species were measles, chicken pox and diabetes (Table 6). Informants insisted that the first two diseases shared the same preparations. Seven modes of preparation were recorded for each of these diseases and the most common was grinding the plant (leaves and stems) in the traditional alcoholic drink, 'sodabi'. Regarding diabetes, similarly to the findings for $P$. amarus, with which this species was usually combined, three types of preparation were noted, the most common being the decoction of the plant (leaves and stems) with oral administration.

\section{Acalypha ciliata}

Only the magic use of this species for luck was considered and six preparations were reported (Table 6). Based on the Fidelity Level, the most common preparation, mentioned by a majority of the traders, involved grinding the plant (leaves and stems) and mixing it with soap for bathing. So the route of 
administration was herbal bathing. This was said by the traders to bring good luck to business activities.

\section{Traders' contribution to species conservation}

The majority of the traders did not plant the four research species (Table 7). However, a low proportion of traders confirmed that they planted $S$. uliginosa and $P$. amarus for trade and personal use. In-situ conservation of the naturally grown populations of all species at home except $S$. uliginosa was reported by a small proportion of traders.

Table 7

Informants' contribution to species conservation

\begin{tabular}{|llll|}
\hline & \multicolumn{2}{l}{ Conserved } & Not conserved \\
\cline { 2 - 3 } & Through planting & In-situ conservation at home & \\
\cline { 2 - 4 } & RFC (\%) & RFC (\%) & RFC (\%) \\
\hline Phyllanthus amarus & 11 & 11 & 78 \\
\hline Spilanthes uliginosa & 22 & 0 & 72 \\
\hline Momordica charantia & 0 & 17 & 83 \\
\hline Acalypha ciliata & 0 & 17 & 83 \\
\hline * RFC (\%) = Relative Frequency Citation (\%). Number of traders = 36 except for S. uliginosa where $\mathrm{n}=34$. \\
\hline
\end{tabular}

\section{Discussion And Conclusions}

\section{Sources plant species traded.}

All informants confirmed the trade of $P$. amarus, M. charantia and $A$. ciliata while $94 \%$ traded $S$. uliginosa. These findings confirmed the medico-magic importance of these four herbaceous species to indigenous people in Benin. In addition, the trade of these species may generate a considerable income to traders. There is an increasing demand for plants for herbal drugs, natural health products and secondary metabolites throughout the world [38]. The majority of traders purchased the four species in their own markets, meaning a close relationship and collaboration between medicinal plant harvesters and local traders. Elsewhere, the relationship between wholesalers and traders of medicinal plants in South Asia seemed to be exploitative [39]. There is a need to better understand this relationship in Africa, especially in Benin. In all cases, there were fewer traders reporting purchasing the four medicinal plants in distant markets. The collection from wild populations of three of the four species, $P$. amarus, $M$. charantia and $A$. ciliata, confirmed the connection of local traders with their environment. Moreover, since there is no control of herbaceous medicinal plant collection from the wild, this harvesting may threaten the conservation of the concerned species. Consequently, further investigation is needed on the harvesting and trade of herbaceous medicinal plants to ensure their long-term sustainable conservation.

\section{Ranking of the four species in terms of demand and availability}

The ranking of $P$. amarus as most demanded by the greatest number of traders showed the importance of this species in health care of the local population. Similarly, M. charantia also has a high importance. The high demand for these two species suggests that there is a likely to higher pressure on the conservation of these species than on the other two. The use of species belonging to the genus Phyllanthus as green medicine is becoming more popular [15]. Momordica charantia is widely used and in demand all over the world for its medicinal potency [40] resulting in over exploitation of its wild populations. Species belonging to the genus Spilanthes are widely used in traditional medicine in various cultures [41]. Knowledge related to the impact of climate change on plant species availability [42] was confirmed by local traders who perceived climate change to be a contributing factor to species scarcity. Additionally, the destruction of species habitats for logging reported by traders confirmed threats to forest biodiversity due to both habitat loss and degradation of forest ecosystems $([43,44]$. Not all medicinal plant species are affected in the same way by harvesting pressure so research is needed to assess the factors affecting the scarcity of each species studied. Herbal traders who reported the planting of $S$. uliginosa in other gardens confirmed the ex-situ conservation of this species. As a result, further investigations should be conducted in gardens to assess the ecological patterns and horticultural practices of these plantings. This will serve to promote cultivation of the species planting throughout the country in gardens.

\section{Diversity of diseases, disorders and magic utilization of species}

The large number of uses recorded for $P$. amarus and $M$. charantia revealed that herbal traders hold a diversity of knowledge on these species. The medicinal potency of $M$. charantia has been widely reported $[40,45,46]$ including its use to treat diabetes as reported in the present study. The use of the species to treat measles was also reported in Nigeria [16], as well as its action against inflammatory diseases [17]. The combination of $P$. amarus with M. charantia for the treatment of diabetes corroborates findings of Sarin et al. [15] who mentioned diabetes among ailments treated with Phyllanthus species. As recorded in the present research, indigenous people in Nigeria used fresh leaves of $M$. charantia in various preparations to treat measles [16]. The medicinal use of this species seems common along the West African coast. Since diabetes is mentioned among the five most lethal diseases in the world [47], further research is needed on the pharmacognosy of $P$. amarus, $M$. charantia and their combination in treating diabetes. Similarly to the present results, the use of Phyllanthus species in the treatment of malaria, liver disorders and constipation was also staded by Sarin et al. [15]. Malaria is 
one of the most lethal diseases in tropical countries so the long-term conservation of medicinal plants, especially $P$. amarus, active in treating malaria in Benin, provides a guarantee for the treatment of this dreadful disease.

Few species of the genus Spilanthes have received research attention for their uses [41]. The magic utilization recorded for the species in this research was a proof of traditional belief that African populations assign to plants. Acalypha ciliata, similarly to $S$. uliginosa, was known as magically efficient by herbal traders. This confirmed the connection of Africans with their nature and the conservation of traditional beliefs across generations. In fact, similar to our findings, Mafimisebi and Oguntade [48] reported magico-religious practices using plant species in Nigeria. Recently, Dossou-Yovo et al. [3] reported the magico-religious practices and rituals using mangrove plant species in Benin. Since people believe that those species bring good luck, this is a strong argument to be used to promote their cultivation and conservation throughout the country.

\section{Relative importance of species and their similarity in terms of uses.}

Despite being the most frequently demanded, $P$. amarus did not have the highest use value. In contrast, $M$. charantia ranked second for demand had a higher use value than $P$. amarus. The relative importance and high demand confirmed the need for sustainable conservation strutegies for $P$. amarus and $M$. charantia as medicinal plants. Spilanthes uliginosa and $A$. ciliata were the least important in terms of uses. Although there was a low similarity in terms of use between $P$. amarus and $M$. charantia, the RSI value indicated that $19 \%$ ailments and disorders could be treated using either $P$. amarus or $M$. charantia. Spilanthes uliginosa and $A$. ciliata with an RSI value of $9 \%$ also had a low similarlity of use. However, the possible substitution of one medicinal plant for another justifies further study as it might contribute to conservation by relieving pressure of exploitation on wild populations of scarce and most threatened medicinal plant species in tropical countries.

\section{Preparation and routes of administration}

Similar to the present findings, aqueous extracts of $P$. amarus were reported as more efficient than ethanol extracts for the treatment of malaria by Ajala et al. [14]. The preference of traders for decoctions with an oral route of administration against malaria matches western medical knowledge and confirmed that indigenous knowledge on green medicine has a great role to play in fighting dangerous diseases worldwide. Phyllanthus amarus was also recorded as the most commonly used in diabetes treatment, predominantly as a decoction with oral route of administration by Thai communities [47]. Constipation is a stomach disorder very often related to dysfunctioning of the liver. Given that excessive alcohol consumption is damaging to the liver [49], the authors question the wisdom of recommending extracts of medicinal plants in alcohol for the treatment of this condition. Spilanthes uliginosa and $A$. ciliata were recorded mainly for their spiritual use for luck and the chewing of leaves or flowers, and the mixture of the ground plant with soap for bathing were the predominant methods of use. Elsewhere, species of the genus Spilanthes were reported as used for more than 60 disorders including parasitic diseases [41]. Herbal bathing as route of administration recorded in this research was also reported by Sabran et al. [50]. The harvesting of fresh flowers of $S$. uliginosa for chewing compromises the reproductive capacity of the species since flowers are reproductive organs.

\section{Traders' contribution to species conservation.}

There is evidence of the important role that in-situ and ex-situ conservation plays in the conservation of plant genetic resources [43]. However, the majority of traders do not plant the medicinal plant species that they sell. Therefore, there is an urgent need to promote the species plantation or the insitu conservation of naturally grown populations of the study species. Traders should be trained and sensitized on tools for the planting of $P$. amarus whenever possible in order to reduce pressure on its wild populations. Momordica charantia, exhibiting a relative high importance in this study, should also be conserved by traders wherever it grows. Although few uses were recorded for $S$. uliginosa and $A$. ciliata, it is recommended that traders also contribute to the in-situ and ex-situ conservation of these species. Those traders who confirmed the planting and conservation of naturally grown populations of the research species should be encouraged to contribute to training and dissemination of conservation tools for these species. Herbaceous species, especially those used as medicine in Benin, are often overlooked by conservation programs. The authors strongly suggest that greater attention should be paid to herbaceous medicinal plants in Benin in order to contribute to their conservation.

\section{Declarations}

\section{Ethics approval and consent to participate}

Not applicable.

\section{Consent for publication}

Not applicable.

\section{Availability of data and materials}

Please contact author for data requests.

\section{Funding}

No funding. 


\section{Competing interests}

The authors declare that they have no competing interests.

\section{Authors' contributions}

Dossou-Yovo H. O. was the originator of the research. He wrote the first draft of the research proposal, participated in the data collection and analysis as well as manuscript writing and its submission.

Kindomihou V. participated in proposal writing, collaborated during data collection and contributed to analysis, manuscript writing and editing.

Sinsin B. as head of the laboratory, he read, edited and commented on the manuscript for its improvement. He provided valuable comments that helped improve the quality of this manuscript.

\section{Acknowledgement}

Authors are deeply grateful to Prof. Phil Harris from Coventry University (England) who read, edited the first draft of this paper and provided relevant comments for its improvement. Thanks are also due to all herbal traders who participated in this research.

\section{References}

[1] Cunningham AB. African medicinal plants. Setting priorities at the interface between conservation and primary healthcare. People and Plants Working Paper 1. UNESCO, Paris. 1993; p. 50.

[2] Dossou-Yovo H O, Vodouhè F G, Sinsin B. Assessment of the medicinal uses of plant species found on termitaria in the Pendjari biosphere reserve in Benin. Journal of Medicinal Plant Research 2014;8(8):368-377. DOI:10.5897/JMPR10.124

[3] Dossou-Yovo H O, Vodouhè F G, Sinsin B. Ethnomedicinal survey of mangrove plant species used as medicine from Ouidah to Gand-Popo Districts, Southern Benin. American Journal of Ethnomedicine 2017;4(1):8. DOI:10.21767/2348-9502.100008

[4] Jones E T, McLain R J, Weigand J. Non-timber forest products in the United States. University Press of Kansas. Lawrence, USA. $2002 ; \mathrm{p} 445$.

[5] Hamilton AC. Medicinal plants, conservation and livelihoods. Biodiversity and Conservation 2004;13:1477-1517.

DOI:10.1023/B:BIOC.0000021333.23413.42

[6] Garedew B, Bizuayehu B. A Review on ethnobotanical study of traditional medicinal plants used for treatment of liver problems in Ethiopia. European Journal of Medicinal Plants 2018;26(1):1-18. DOI: 10.9734/EJMP/2018/38153

[7] Tounekti T, Mahdhi M, Khemira H. Ethnobotanical study of Indigenous Medicinal Plants of Jazan Region, Saudi Aradia. Evidence-Based Complementary and Alternative Medicine, Hindawi. 2019; Article ID 3190670. 45p. https://doi.org/10.1155/2019/3190670.

[8] Shaheen HS, Qureshi R, Qaseem, Amjad MS, Bruschi P The cultural importance of indices: A comparative analysis based on the useful wild plants of Noorpur Thal Punjab, Pakistan. European Journal of Integrative Medicine. 2017;12:27-34.

[9] Khan I, AbdElsalam NM, Fouad H, Tariq A, Ullah R, Adnan M. (2014). Application of Ethnomedicinal Indices on the Use of Traditional Medicines against Common diseases. Evidence-Based Complementary and Alternative Medicine. Hindawi Publishing Corporation 2014; Article ID 635371, 21p. http://dx.doi.org/10.1155/2014/635371

[10] Hoffman B, Gallaher T. Importance indices in ethnobotany. Ethnobotany Research \& Applications 2007;5: 201-218. DOI:10.17348/era.5.0.201-218

[11] Prance GT, Balee W, Boom BM, Carneiro RL. Quantitative ethnobotany and the case for conservation in Amazonia. Conservation Biology 1987; 1:296-310.

DOI: $10.1111 / \mathrm{j} .1523-1739.1987 . t b 00050 . x$

[12] Phillips O, Gentry AH. The useful plants of Tambopata, Peru: I. Statistical hypotheses tests with a new quantitative technique. Economic Botany 1993; 47(1):15-32. http://www.jstor.org/stable/4255479

[13] Phillips O, Gentry AH. The useful plants of Tambopata, Peru: Il. Additional hypothesis testing in quantitative ethnobotany. Economic Botany 1993;47:33-43. http://www.jstor.org/stable/4255480Acc

[14] Ajala T O, Igwilo C I, Oreagba IA, Odeku O A. The autiplasmodial effect of the extractsand formulated capsules of Phyllanthus amarus on Plasmodium yoelii infection in mice. Asian Pacific Journal of Tropical Medicine 2011;283-287. DOI: 10.1016/S1995-7645(11)60087-4

[15] Sarin B, Verma N, Martin JP, Mohanty A . An overview of important ethnomedicinal herbs of Phyllanthus species: Present status and future prospects. The Scientific World Journal, Hindawi. 2014;Article ID 839172: 12 pages http://dx.doi.org/10.1155/2014/839172

Page 11/13 
[16] Sonibare MA, Moody JO, Adesanyo EO. Use of medicinal plants for the treatment of measles in Nigeria. Journal of Ethnopharmacology. 2009;122(2):268-72. doi: 10.1016/j.jep. 2009.01.004.

[17] Bartolotti M, Mercatelli D, Polito L Momordica charantia, a neutraceutical approach for inflammatory related diseases. Frontiers in Pharmacology 2019;10:486. doi: 10.3389/fphar.2019.00486

[18] Boko-Haya YY, Ouinsavi C, Houngbeme A, Gbaguidi F. Ethnic differences in use, phytochemical screening and non-poisonous leaves of Phyllanthus amarus (Schum. \& Thonn.) in North of Benin. The Journal of Ethnobiology and Traditional Medicine. Photon 2016;126:1185-1196.

[19] Adjobimey T, Edayé I, Lagnika L, Gbenou J, Moudachirou M, Sanni A. . In vitro antiplasmodial activity of some antimalarial plants of Beninese pharmacopoeia. Comptes Rendus Chimie 2004;7:1023-1027. doi:10.1016/j.crci.2003.10.022

[20] Bano A, Ahmad M, Hadda TB, Saboor A, Sultana S, Zafar1 M, et al. (2014). Quantitative ethnomedicinal study of plants used in the skardu valley at high altitude of Karakoram-Himalayan range, Pakistan. J Ethnobiology Ethnomedicine 2014; 10:43 https://doi.org/10.1186/1746-4269-10-43

[21] Amjad MS, Qaeem MF, Ahmad I, Khan SU, Chaudhan SK, Zahid Malik N. et al.. Descriptive study of plant resources in the context of the ethnomedicinal relevance of indigenous flora: A case study from Toli Peer Natonal Park, Azed Jammu and Kashmir, Pakistan. PLoS ONE 2017;12(2): e0171896. Doi: 10.1371/journal. Pone. 0171896

[22] Ugulu I. Traditional ethnobotanical knowledge about medicinal plants used for external therapies, Turkey. Int. J. Msd. Arom. Plants. 2011; 1(2): 101-106. Available from http://www.openaccessscience.com/

[23] Ugulu I, Baslar S. The determination and Fidelity Level of medicinal plants used to make traditional Turkish salves. Journal of Alternative and complementary Medicine. 2010; 16(3):313-322. DOI:10.1089/acm.2009.0040

[24] Padhan B and Panda D. Wild tuber species diversity and its ethnomedicinal use by tribal people of Koraput district of Odisha, India. Indian Journal of Natural Products and Resources 2016;2(1):33-36.

[25] Zenderland J, Hart R, Bussmann RW, Paniagua Z, Narel Y, Sikharulidze, S, et al. The use of "Use Value". Quantifying importance in ethnobotany. Economic Botany. 2019; 73:293-303. http://dx.doi.org/10.1007/s12231-019-09480-1

[26] Rahman IU, Hart R, Afzal A, Iqbal Z, ljaz F, ABD_Allah EF, et al. A new ethnobiological similarity index for the evaluation of novel use reports. Applied Ecology and Environmental Research 2019;17(2):2765-2777. DOI: 10.15666/aeer/1702_27652777

[27] Rajeswara Rao BR. (2012). Cultivation, Economics and Marketing of Phyllanthus Species. In Kuttan R, Harikumar KB. (Eds). Phyllanthus Species: Sceintific Evaluation and Medicinal Applications (pp.47-70). Edition: 1 Chapter: 3. Publisher: CRC Press, Boca Raton, USA. DOI: 10.1201/b11380-4

[28] Matou M., Bercion S, Merciris P, Meyssonier N, Fernand D, Marianne-Pepin T. Etude de la composition chimique et du potentiel pharmacologique associé de Phyllanthus amarus Schum et Thonn. (1827) " Grenn anba fèy ». Colloque International des Plantes Aromatiques et Médicinales (CIPAM) 9ème édition, Nov 2016, Cayenne, Guyane française.〈hal-01827968〉

[29] Tiwari KL, Jadhav SK, Joshi V. An updated review on medicinal herb genus Spilanthes. Journal of Chinese Integrative Medicine. 2011; 9(11):11701178. DOI: 10.3736/jcim20111103

[30] Iwu MM. Handbook of African Medicinal Plants. Edition CRC Press. 2014; 506p. pp. 31-35.

[31] Jia S, Shen M, Zhang F, Xie J. Recent Advances in Momordica charantia: Functional Components and Biological Activities. Int J Mol Sci. 2017;18(12): 2555. doi: 10.3390/ijms18122555.

[32] Schaefer H, Renner SS. A three-genome phylogeny of Momordica (Cucurbitaceae) suggests seven returns from dioecy to monoecy and recent long-distance dispersal to Asia. Molecular Phylogenetics and Evolution. 2010; 54(2): 553-560. https://doi.org/10.1016/j.ympev.2009.08.006

[33] Kumar KPS, Bhowmik D. Spilanthes uliginosa is used for dental problems and for its antiseptic, homeostatic, analgesic, insecticidal and antiinflammatory activity. International Journal of Pharmaceutical Sciences Review and Research. 2010; 4(3): 23-28.

[34] Owolade OF, Amusa AN, Osikanlu, YOK,. Efficacy of certain indigenous plant extracts against seed-borne infection of Fusarium moniliforme on maize (Zea mays L.) in south western Nigeria. Cereal Research Communications 2000;28(3): 323-327. D0I: 10.1007/BF03543611

[35] Owolade OF, Alabi BS, Osikanlu YOK, Odeyemi OO, On-farm evaluation of some plant extracts as biofungicide and bioinsecticide on cowpea in Southwest Nigeria. Journal of Food, Agriculture and Environment 2004;2(2): 237-240. https://worldveg.tind.io/record/37631/

[36] Schmelzer GH. Acalypha ciliata Forssk. [Internet] Record from Protabase. Schmelzer GH. \& Gurib-Fakim A. (Editors). PROTA (Plant Resources of Tropical Africa / Ressources végétales de l'Afrique tropicale), Wageningen, Netherlands. 2007;< http://database.prota.org/search.htm>. Accessed 
[37] Tewari D, Mocan A, Parvanov ED; Sah AN, Nabavi SM, Huminiecki L, et al. "Ethnopharmacological Approaches for Therapy of Jaundice: Part I". Frontiers in Pharmacology. 2017; 8: 518. DOI:10.3389/fphar.2017.00518..

[38] Chen SL, Yu H, Luo, HM, Wu Q, Li CF, Steinmetz A. Conservation and sustainable use of medicinal plants: problems, progress, and prospects. Chinese Medicine 2016;11:37. DOI 10.1186/s13020-016-0108-7.

[39] Olsen CS, Helles F. Market efficiency and benefit distribution in medicinal plant market: empirical evidence from South Asia. International Journal of Biodiversity Science \& Management 2009;5(2):53-62. DOI:10.1080/17451590903063129

[40] Kumar DS, Sharathnath KV, Vogeswaran P,Harami A, Sudhakar K, Sudha P, Bandji D. A medical potency of Momordica charantia. Int.J. Pharm. Sc. Res. 2010;1(2):95-100.

[41] Paulraj J, Govindarajan R, Palpu P. The genus Spillanthes. Ethnopharmacology, Phytochemistry, and Pharmacological Properties: A review. Advances in Pharmacological Sciences.2013; 510298. DOI: 10.1155/2013/510298.

[42] IUCN. Species and Climate Change. 2020; www.iucn.org

[43] Rudebjer P, Eyog-Matig O, Thomson L. Biodiversity in Forestry Education: what needs to change. Bioversity International. In Temu AB; Chamshama SAO, Kung'u J; Kaboggoza J; Chikamai B; Kiwia A (eds.) 2008. New Perspectives in Forestry Education. Peer reviewed papers presented at the First Global Workshop on Forestry Education, September 2007. ICRAF, Nairobi, Kenya New perspectives in Forestry Education. 2008; pp. 270-286.. Available from

https://www.bioversityinternational.org/fileadmin/_migrated/uploads/tx_news/Biodiversity_in_forestry_education_what_needs_to_change_1834_02.PDF

[44] Javed A, Afaq AM, Leena S. Urban development: A threat to wild species of medicinal and aromatic plants. Middle-East Journal of Scientific Research 2013;13 (7):947-951. DOI: 10.5829/idosi.mejsr.2013.13.7.3009

[45] Joseph B, Jini D. Insight into the hypoglycaemic effect of traditional Indian herbs used in the treatment of diabetes. Res. J. Med Plants 2011;5(4):352-376. DOI:10.3923/rjmp.2011.352.376

[46] Joseph B, Jini D.. Antidiabetic effect of Momordica charantia (bitter melon) and its medicinal potency. Asian Pacific Journal of Tropical Disease 2013;3(2):93-102. https://www.ncbi.nlm.nih.gov/pmc/articles/PMC4027280/pdf/apjtd-03-02-093.pdf

[47] Phumthum M, Basler H. Thai ethnomedicinal plants used for diabetes treatment. OBM Integrative and complementary Medicine 2018;3(3):1-25.

[48] Mafimisebi TE, Oguntade AE. Preparation and use of plant medicines for tarmers' health in Southwest Nigeria: socio-cultural, magico-religious and economic aspects. J Ethnobiol Ethnomed 2010;6:1. DOI:10.1186/1746-4269-6-1

[49] Osna N A, Donohue T M, Kharbanda K K Alcoholic Liver Disease: Pathogenesis and Current Management. Alcohol Res. 2017;38(2):147-161. https://www.ncbi.nlm.nih.gov/pmc/articles/PMC5513682/pdf/arcr-38-2-147.pdf

[50] Sabran SF, Mohamed M, Bakar MFA. Ethnomedical knowledge of plants used for the treatment of tuberculosis in Johor, Malaysia. EvidenceBased Complementary and Alternative Medicine, Hindawi. 2016; Article ID 285084512p. http://dx.doi.org/10.1155/2016/2850845 